\title{
AUTOMOTIVE TEACHERS INDUSTRIAL INTERNSHIP TO OBTAIN VOCATIONAL SCHOOL GRADUATES DEMANDED BY THE INDUSTRY
}

\author{
Sutijono S. ${ }^{*}$, Kustono D., Sutikno T.A. \\ University of Negeri, Malang, Indonesia \\ Sutrijono S. \\ National Institute of Technology, Indonesia \\ *E-mail: sutijono@yahoo.com
}

\begin{abstract}
Vocational school is a secondary school of which purpose is to equip students with conceptual knowledge and skills in technology as well as professional vocational skills that meets the demand of the society. Science and technology have always evolved rapidly. Teachers should keep updating their knowledge, especially one related to the current demand of the industry so that they will not be left behind because the knowledge they learned at school may be different from it is now. The study is a qualitative study of which objects are two public and private vocational schools concentrating in automotive located in Sidoarjo. The findings reveal that industrial internship for vocational school teachers needs to be conducted and the two vocational schools have conducted one. The internship allows the teachers to teach their students about the culture, and current development of science and technology in the automotive industry.
\end{abstract}

\section{KEY WORDS}

Vocational school teachers, industrial internship, industry, graduates.

Change in education system is a need because science and technology constantly change. Vocational School functions as the sub-system going with the change in Indonesian education system; thus, there is a changing paradigm in Indonesian vocational school, namely: (1) from supply driven to demand driven, (2) from academic oriented to job oriented, and (3) from school based program to dual base program. The paradigm suits the vision and mission of the vocational school development in Indonesia (Depdikbud, 1999).

Process of developing skills and knowledge involves teachers, coaches and instructors who individually and directly encourage vocational learning process. Therefore, as facilitators the teachers, coaches and instructors should understand the concept of livelong learning because the concept is considered as one of the cores of professionalism in education by the society. Developing teachers, coaches and instructors' quality is a meaningful effort to enhance the quality of vocational education (Grollman and Rauner, 2007: 2).

Education and training are two methods to improve the quality of education and work force (Sutrisno, 2006). Education and training are ways to prepare well-competent work force who can meet the demand of the business world and industry (DU/DI). Vocational school has very strategic and significant roles to prepare workforce from secondary school background. In relation to this, developing the quantity and quality of vocational school is a requirement to prepare the workforce whose role is the assets for the development.

Teacher and academic staff are a vital support in terms of input because no matter how good other support systems are, developing quality of vocational education is not going to be effective without well-qualified teachers and academic staffs. Science and technology keeps growing and evolving and as the consequence various efforts to be taken; training is one of them. It is in line with the 2005 Decree number 14 and the 2008 Regulation number 74 about teachers that ask teachers to have academic qualification, competent and teaching certificate. The minimum academic qualification for vocational school teachers is bachelor or 
a four-year diploma degree. Teacher competence involves pedagogic, personal, social and professional competence.

The Teacher Professional Development Policy (2012: 19) issued by the Ministry of Education and Culture's Human Resource Development Agency of Education and Culture and Agency of Quality Assurance in 2012 states that the format of education and training and non-training are 1) in house training, 2) internship, 3) school partnership, 4) long distance learning, 5) graded and special training, 6) short course in vocational training center or other vocational institutions, 7) school internal development, and 8) further education.

Internship is a program carried out in the industry or other relevant institutions in order to improve professional competence. The program is specifically designed for vocational school teachers and done within particular period of time. Vocational school teachers need real experience in their field. Industrial internship program is an alternative to improve teacher's competence. Vocational school teachers have to prepare their students to meet the need of business world and the industry. Vocational school graduate's competence should meet the competence required by the business and industry. School main component closely related to achieving the competent is teacher. Vocational school teachers should share their experiential learning in order to make students having competence needed by the industry and business world. Hence, teachers should have knowledge and experience how the business world and industry work. Problem arises since many vocational school teachers have zero hands-on experience in business and the industry. Imob Educare (2011) argues that majority of vocational school teachers have yet been able to deliver a lesson that suits the need of the workforce.

Lee (2011) conducted a study about software application internship where 24 teachers became the subjects. At the end of the study, all 24 teachers successfully developed their own computer education program in education technology course through cognitive internship. The results of the anonymous survey that evaluates difficulties and attitudes towards Etoys learning show that the teachers have positive attitude toward Etoys learning and intend to keep using the method despite the fact that the learning is more difficult for their levels of computer skills. In conclusion, teacher internship develops teacher professionalism.

Brujin and Leeman (2011) and Dickey (2008) conducted studies on cognitive internship. The cognitive internship involves mentoring process. The cognitive internship improves the teacher's competence in the form of metacognitive, skill and flexibility.

Teacher internship is a form of training. Ruys, Kerr, and Aelterman (2011) conducted training with 105 teachers as participants using collaborative learning method. The finding reveals that in general the participants can apply collaborative learning well. Teemant, Wink, and Tyra (2011) also find out that mentoring process in sociocultural teaching has significantly improves (a) teacher's pedagogy, (b) teacher's pattern of development, and (c) changes in classroom organization.

Carayannis and Jorge (1998) in their study reveal that the industry expects skillful and flexible employees who are willing to keep up with the development of technology. In order to obtain employees with such qualifications, the industry should conduct trainings and development. The training and development should be carried out to all stake holder including vocational school teachers. In Germany, vocational education represents qualification that provides well-qualified employees built socially. As a conclusion, business world and the industry are involved and responsible for providing well-competent employees (Clark \& Winch, 2007: 14-15).

Industrial internship is a learning process alternative carried out in a place where one is able to apply technology directly. Because of constant development in technology, industrial internship should keep going. Emada (2010) explains that a change at work happens due to the application of new technology and, as the result, the training participants should be introduced to the most current technology. Hence, education system and vocational training suitable with vocational context have to be applied. It is supported by Gerard (2012) who states that internship results in learning process from individuals with suitable knowledge and 
skills to internees. Gerard finds out that in Morocco the Moslem group with low-income passes their handicraft skills through internship.

The purpose of the study is to explore industrial internship for vocational school productive teachers concentrating in automotive. The purposes of the study are 1) give overview of the implementation of industrial internship for vocational school productive teachers concentrating in automotive; 2) describe effects of industrial internship for vocational school productive teachers concentrating in automotive; and 3) create abstract theoretical foundation from the data from the industrial internship for vocational school productive teachers concentrating in automotive to improve teacher's competence.

Based on the elaboration, the focus of the study is implementation of industrial internship for vocational school productive teachers concentrating in automotive (a case study in SMK (Sekolah Menengah Kejuruan or Public Vocational High School) Krian 2 representing private vocational school in Sidoarjo and SMK Negeri 3 Buduran representing public vocational school in Sidoarjo). The vocational schools are selected as the setting for the study because 1) both vocational schools has light vehicle engineering concentration; 2) the schools have the ISO 9001:2008 standard; 3) the schools have excellent accreditation, 4) they have conducted industrial internship for all productive automotive teachers, and 6) their light vehicle engineering concentration has lasted for 10 years.New paragraph: use this style when you need to begin a new paragraph.

\section{METHODS OF RESEARCH}

The study uses multi-site qualitative approach. Purposive sampling is the method to determine the subjects of the study. The sampling principle is two different category of vocational school, public and private vocational school; SMK Negeri 3 Buduran represents public vocational school, while SMK Krian 2 represents private vocational school. Both schools have conducted industrial internship for their productive automotive teachers. The places for the industrial internship are automotive industry, automotive repair station, and vocational training center that has automotive training program. Data collection methods are observations, interviews and documentation.

Data analysis is conducted starting from field data collection stage and after all data have been conducted, in reference to Moleong (2007: 247), Iskandar (2013: 224), Miles and Huberman (1992), Yin (2011: 177), Creswell (2009:190), and Bogdan and Biklen (1982)'s theories. The data analysis is conducted using a method for each site that involves 1) expert validation/ review, 2) continuous observations, and 3) triangulation.

\section{FINDINGS AND DISCUSSION}

Based on the data from the observations, interviews and documentations that have been through the triangulation, it is found out that SMKN 3 Buduran and SMK Krian 2 have conducted industrial internship. In order to carry out the internship, the schools have collaboration with 1) automotive industry, 2) automotive repair station, and 3) vocational training center with automotive training program. The internship is really effective to improve the teachers' teaching performance at schools. It allows them to get up-to-date theoretical and practical concepts in automotive. As the result, the materials they deliver at school are closely related to the real-life practice.

Billet (2011: 220) states that teacher's comprehension and belief dictate what they teach to the students. When teachers do not participate in the industrial internship, they will not deliver any materials suitable with the development of business world and the industry. The cause is teachers do not keep updating their knowledge to meet the growth of technology in the world of business and the industry. Due to the rapid growth in technology, teachers should have strong motivation for livelong learning (Finsterwald, et.al. 2013) in order to be professional teachers (Avalos, 2011; Mitkovska, 2010). Teacher internship in automotive industry is an effort towards teacher professional development. Teacher 
professional development affects teacher's growth, teaching techniques teachers use, as well as students learning (Glazera, 2006).

According to Miller (1985: 31-36), essentially, having experiment in the industry is needed by teachers because teachers, similar to students, should keep learning throughout their lives to become a whole individual. So, internship or job training in the business world or the industry for vocational school teachers has to be formulated comprehensively and a continuous program. Periodic experience in the business world and the industry let teachers refresh their capability so that learning materials and activities at schools are related to technological transformation in the industry. One method to develop teacher professional development, specifically productive teachers, is through industrial internship.

Learning process at workplace can also be called industrial internship. The definition of industrial internship is work-based learning (Velzen, et.al, 2012) where teachers get guidances from instructors appointed by a company in order to create learning with some guidance from colleague. Internship process is learning activities taking place in sociocultural atmosphere (Ruedaa, 2002).

Industrial internship for teachers results in teaching and learning process. Teachers will obtain some experience that will increase their professional competence as teacher. Teacher will be able to design a better learning process (Hoogveld, et.al, 2005). Teacher industrial internship is performance-based learning process to enhance teacher's pedagogical competence, teacher's pattern of growth as well as change in class organization (Teemant, 2011).

Strenght in learning quality is a key factor to support efctive learning (OECD, 2011: 92). Effective learning encourage and help students achieving well-qualified learning process (Parpala, 2007). Learning strength is determined by how much comprehension teachers have towards a concept they are teaching and skills they have related the topic. Knowledge and skills teachers have should always be updated (OECD, 2011: 93) so that vocational school teachers should spend half of their time to work in the industry to update knowledge and skills they have. Teachers may be a little bit hesitated to do that due to their teaching load; however having experience in the industry is a necessity. Therefore, a solution countries belong to the OECD has is to give incentive (OECD, 2011: 93).

A professional teacher is required to have certain minimum standardized requirement, for instance adequate level of education, pedagogical competence suitable to the field she/he is teaching, good interpersonal communication, creative and productive entity, strong work ethic, strong professional commitment and constant willingness for self-development (Sidi, 2003: 38-39). A characteristic of a professional teacher is a strong will to change into a better version of himself or herself professionally.

Internship Places for Vocational School Productive Automotive Teachers. Based on the findings of the study, the places for the vocational school productive automotive teachers internship program are 1) automotive industry (car, motorcycle and heavy equipment), 2) authorized repair station of various car and motorcycle brands, 3) individually run repair station that takes care of various tasks of new vehicle, and 4) vocational education center with automotive training program (P4-TK, BLKI). The automotive industries where the teachers can have their internship are PT Toyota Motor, PT Hino, Mitsubishi Motor, UMC Suzuki Motor, Honda Motor, and Yamaha Motor among others. Those are leading vehicle brands in Indonesia. Each has program for vocational school teachers who teach automotive. The number of automotive vocational school teachers is far beyond the number of the automotive industry/dealership. As the consequence, not all vocational school productive teachers have an opportunity to have internship in those places.

Toyota Astra Motor through the Toyota Technicians Education Program (T-TEP) and sub-T-TEP gives opportunities for vocational school automotive teachers to have internship in Toyota Motor Company. Since 1993, the Toyota Astra Motor has given 43 vocational school teachers around Indonesia to have internship in Toyota Astra Motor (Berita tentang SMK, 2008). The vocational school teachers get some information about the development of the most current technology in automotive industry. The support given is in the form of teaching curriculum, teaching media, tools for practice and teacher training. 
Indomobil Nissan is one of the largest automotive company which runs its business as Indonesian dealer for Nisan.The company was established in 1986 and its headquarter is located in Jakarta, Indonesia. Related to development and business expansion, the company opens job vacancy for best candidates from Indonesia (BKK FT UNY, 2013) for some of the following positions such as (1) Service Advisor (SA), (2) Service Advisor (internship program SA), and (3) Part Inventory Control (PIC). Besides Indomobil Nissan, Suzuki Indo-mobil also have internship program for vocational school teachers. From November 3 to November 5, 2008, the Indonesian Association of Automotive Teachers conducted national training for automotive teachers in corporation with Suzuki Indomobil (AGTO Indonesia, 2008). The program is one of Corporate Social Responsibility (CSR) programs.

CEO should realize that in order to have competent, skillful employees industry should have active participation to prepare well-qualified employees. Good employees are ones that are able to keep up with the growth of technology in the industry (Carayannis \& Jorge, 1998). The role of the industry is to give internship opportunity for both students and teachers.

Suitable place for vocational school productive teacher professional development is the industry. Vocational school prepares students to enter workforce (Djojonegoro, 1998:36). The 1990 Regulation number 29 states that "secondary vocational education emphasizes on preparing students to enter the workforce as well as develop professionalism." There is a limited opportunity for vocational school productive teacgers to have internship in automotive industry because of the current condition of Indonesian automotive industry. Program automotive industry has is to have teacher internship program in the form of a two-to-threeday training program. Industries invite vocational school productive automotive teachers to join the training program. Honda, Yamaha, and Suzuki run the program. The program is conducted when the company is renewing their products. Before the product is launched, teachers are invited to join short training. The purpose of the training is introducing the new product and promotion.

During the industrial internship, the teachers get some guidance from instructors appointed by the industry. The industrial internship involves instructors/ counselors who work for and appointed by the industry. The instructor is a skillful employee so that for the teachers the instructor is a skillful colleague (Velzen, 2012). The instructor should have adequate level of knowledge and skils. Besides having good communication skill, the instructor should also be willing to help the teachers. Industrial facilities are in the form of industrial facilities, for example tools the industry is using and place for doing industrial activities.

Automotive industry and authorized repair station can only accept limited number of teachers as internees. Thus, school principals also use individually run repair station for the industrial internship program. SMK Krian 2 works together with individually run repair station to find out the most current technology in the society. It is done because there are 12 productive automotive teachers in the school. When teachers should wait for automotive industry or authorized dealer for internship opportunity, they will have to wait for a long time. Industrial internship is conducted during school break. Different from SMK Krian 2, SMK Negeri 3 works together with some automotive industries and authorized repair stations such as PT.Toyota Auto 2000, PT Suzuki motor, Honda motor, Yamaha motor,and PT. Hino. Besides those industries, the school also uses vocational training center called P-4 TK located in Malang. There are only 5 productive automotive teachers in SMK Negeri 3 Buduran.

Another effort to improve the productive teacher competence is through vocational training center that has automotive training program (P4-TK, BLKI). The P4 -TK located in Malang has automotive training program; the program is not a regular program because the institution has to wait for funding from the government. The government funding is limited to be able to recruit participants for the training. BLKI as government-run vocational training center owned by the Ministry of Labor is also used to improve the automotive teacher professional development. However, in both P4-TK and BLKI, the materials given to the participants are different from those given by either automotive industry or authorized repair station. In automotive industry or authorized repair station, teachers will get the most current automotive knowledge and skills. 
Industrial Internship Impact towards Learning at School. Teachers are professional whose main responsibilities are to educate, teach, guide, facilitate, train, asses and evaluate students' learning outcome (Barnawi\&Arifin, M, 2012:13). Teacher performance can be defined as teacher's success in carrying out his/her role in accordance to his/her right and responsibility based on the standardized criteria that has been established in certain time period in order to achieve goals of learning (Barnawi\&Arifin, M, 2012:14). Schippers \& Patriana (1994:23) as stated in Firdausi.A\&Barnawi explain in order to have successful creation an individual should have complete behavioral competence. The complete behavioral competence is obtained through lifetime education, training and practical experience.

The teachers consider the industrial internship as their necessities. As the effect, they have willingness and strong motivation to have the internship. Having finished their internship, the teachers are able to develop learning process similar to one they have during their internship. The developments the teachers do at schools are in the form of team teaching model and group work where each group is assigned different tasks; all students participate actively in the activities. The activities are carried out despite of limited number of facilities at the school workshops and big number of students. Not only do the teachers intoduce the most current automotive technology to the students, but they also introduce the safety procedure at work, the concept the teachers learn during their industrial internship. The students can feel the improvement their teachers made, for example the use of scan tool which is a relatively new device for the students. Furthermore, the teachers have more confidence because they feel that the knowledge and skills they have suit the current development of the automotive industry.

\section{CONCLUSION}

Based on the findings and discussions, some conclusions to draw are 1) industrial internship is needed to be implemented; 2) opportunity for teacher internship is still limited; 3) teachers should take turns for conducting the internship; 4) automotive industry (cars, motorcycles, heavy equipment), authorized repair stations (motorcycles and cars), repair station run by individuals focusing on new vehicle multi repair, and vocational training station with automotive training program are suitable places for the internship; 5) industrial internship for productive teachers enhance their confidence in the implementation of teaching and learning process at school; 6) having finished the internship, the teachers feel that they have adequate knowledge and skills that meet the development of knowledge and skills in the society; and 7) internship is an effort for teacher development.

\section{RECOMMENDATION}

Based on the findings, discussions and conclusion, some recommendations are given to related parties. The suggestions are 1) automotive, both car and motorcycle, industry and authorized repair station should have internship program for productive teachers conducted anytime or regularly so that teachers get wide opportunity for industrial internship; 2) local government should support the program by giving some incentives for automotive industry and/or repair station that provides opportunity for teacher internship regularly and throughout the year. As the effect, more teachers get their internship and vocational school graduates become professional employees that meet the demand of the industry; and 3) both public and private vocational schools through the Musyawarah Kerja Kepala Sekolah (School Principals Association) should work together with the local Office of Education Affairs to have collaboration with the association whose members are individually run repair stations in order to identify, establish and work together to provide places for productive teacher internship. It is expected all productive teachers can have their internship throughout the year and their waiting time is going to be less long. 


\section{REFERENCES}

1. AGTO Indonesia. 2008. Pelatihan Guru Otomotip Nasional. (online). http://agtoindonesia. blogspot.com/2008/11/pelatihan-guru-otomotif-nasional.html. Retrieved on June 7, 2013.

2. Avalos, B. 2011. Teacher Professional Development in Teaching and Teacher Educationover Ten Years. Teaching and Teacher Education 27 (2011) 10e20.

3. Barnawi and M. Arifin. 2012. Kinerja Guru Profesional, Jakarta: Ar-Ruzz Media

4. Berita tentang SMK. 2008. SMK Diprioritaskan. (online). stembasurabaya.wordpress.com/2008/08. Retrieved on June 7, 2013.

5. Billett, S. 2011. Vocational Education, London: Springer

6. BKK FT UNY. 2013. Lowongan Indomobil Nissan. (online). http://bkkftuny.blogspot.com/2013 /05/lowongan-indomobil-nissan.html. Retreived on June 7, Juni 2013.

7. Bruijn, E.,D. \& Y. Leeman. 2011. Authentic and Self-directed Learning in Vocational Education: Challenges to Vocational Educators. Teaching and Teacher Education 27, $694 \mathrm{e} 702$.

8. Carayannis, E.G. and J. J. Jorge. 1998. Bridging Government-University-Industry Technological Learning Disconnects: a Comparative Study of Training and Development Policies and Practices in the U.S, Japan, Germany, and France. Technovation, 18(6/7) (1998) 383-407.

9. Clark, L. and L. Winch. (Eds). 2007. Vocational Education: International Approaches, Developments and Systems. London: Routledge.

10. Creswell, W.J. 2009. Research Design. Singapore: Sage Publications, Inc.

11. Dickey, M.D. 2008. Integrating Cognitive Apprenticeship Methods in a Web-Based Educational Technology Course for P-12 Teacher Education. Computers \& Education 51 (2008) 506-518.

12. Djojonegoro, W. 1998. Pengembangan Sumber Manusia Melalui Sekolah Menengah Kejuruan (SMK). Jakarta: PT Jayakarta Agung Offset

13. Emada, R.G. 2010. Introduction of technology into workplace and the need for change in pedagogy. Procedia Social and Behavioral Sciences 2 (2010) 875-879.

14. Finsterwald, M. et al. 2013. Fostering lifelong learning e Evaluation of a teacher education program for professional teachers. Teaching and Teacher Education 29 (2013) 144-155.

15. Firdausi, A and Barnawi. 2012. Profil Guru SMK Profesional. Yogyakarta: Ar-Ruzz Media.

16. Gerard, E. 2012. Scholarisation, Aprenticeship and Social Differentiation. Analysis of The Non-Industrial Craft Sector in Morocco. International Journal of Educational Development 32 (2012) 172-178.

17. Glazera, M.E., and J.M. Hannafin. 2006. The Collaborative Apprenticeship Model: Situated Professional Development within School Settings. Teaching and Teacher Education 22 (2006) 179-193.

18. Grollmann, P., and F. Rauner. 2007. TVET Teachers: An Endangered Speciesor Professional Innovation Agents?, International Perspectives on Teacher and Lecturers in Technical and Vocational Education. Netherland: Springer.

19. Hoogveld, W.M.A., F. Paas, and M.G.W. Jochems. 2005. Training Higher Education Teachers for Instructional Design of Competency-based Education: Product-oriented versus Process-oriented Worked Examples. Teaching and Teacher Education 21 (2005) 287-297.

20. Huang, K., A.I. Lubin, and X. Ge. 2011. The Situated Learning Environment Demonstrated Sophisticated Problem-solving Skills, Exhibited Metacognitive Awareness, Produced Coherent Artifacts, and Showed High Levels of Motivation. Teaching and Teacher Education 27 (2011) 1200-1212.

21. Imob Educare. 2011. Antara Pengalaman Guru dan Kesiapan Sarana Pendukung. (online), (http://www.imobeducare.com/story/antara-pengalaman-guru-dan-kesiapansarana-pendukung), retrieved on October 29, 2012.

22. Iskandar. 2013. Metodologi Penelitian Pendidikan dan Sosial. Jakarta: Referensi. 
23. Kementerian Pendidikan dan Kebudayaan. 2012. Kebijakan Pengembangan Profesi Guru. Jakarta: Badan PSDMPK-PMP

24. Lee, J.Y. 2011. Empowering Teachers to Create Educational Software: A Constructivist Approach Utilizing Etoys, Pair Programming and Cognitive Apprenticeship, Computers \& Education 56 (2011) 527-538).

25. Miller, D., M. 1985. Principle and a Philosophy for Vocational Education, Ohio: Columbus.

26. Mitkovska, J., S. 2010. The Need of Continuous Professional Teacher Development. Procedia Social and Behavioral Sciences 2 (2010) 2921-2926

27. Moleong, L. J. 2007. Metodologi Penelitian Kualitatif. Bandung: Remaja Rosadakarya.

28. OECD. 2010. Learning for Job, Corrigenda to OECD Publication may be found on line: www.OECD.org/publishing/corrigenda

29. Parpala, A., \& Lindblom-Ylänne, S. 2007. University Teachers' Conceptions of Good Teaching in the Units of High-Quality Education. Studies in Educational Evaluation 33 (2007) 355-370.

30. Pendidikan dan Latihan Profesi Guru Badan Pengembangan Sumber Daya Manusia Pendidikan dan Kebudayaan dan Penjaminan Mutu Pendidikan Kementerian Pendidikan dan Kebudayaan. 2012. KEBIJAKAN PENGEMBANGAN PROFESI GURU

31. Ruedaa, R.,\& Monz!ob, D., L. 2002. Apprenticeship for Teaching: Professional Development Issues Surrounding the Collaborative Relationship between Teachers and Paraeducators. Teaching and Teacher Education 18 (2002) 503-521.

32. Sidi, D., I., 2003, Menuju Masyarakat Belajar: Menggagas Paradigma Baru Pendidikan, Jakarta: Paramadina \& Logos Wacana IImu.

33. Sutrisno, Joko. 2006. Penyelenggaraan Sekolah Menengah Kejuruan Bertaraf Internasional. Jakarta: Directorate General of Elementary and Secondary Education.

34. Teemant, A., Joan Wink, J., \& Tyra, S.2011. Effects of Coaching on Teacher Use of Sociocultural Instructional Practices. Teaching and Teacher Education 27 (2011) 683693

35. Velzen, v., C., Volman, M., Brekelmans, M., \& White, S . 2012. Guided Work-based Learning: Sharing Practical Teaching Knowledge with Student Teachers. Teaching and Teacher Education 28 (2012) 229-239. 